\title{
PENGGUNAAN STRATEGI THINK, TALK, WRITE (TTW) TERHADAP SIKAP PERCAYA DIRI SISWA SEKOLAH DASAR
}

\author{
Dhuhita Ayuning Tyas*, Karma Iswata Eka, Cici Wiarsih
}

PGSD, Universitas Muhammadiyah Purwokerto, Indonesia

\begin{tabular}{|c|c|}
\hline History & \multirow{6}{*}{$\begin{array}{l}\text { Abstrak } \\
\text { Artikel ini bertujuan untuk melihat adanya peningkatkan sikap percaya } \\
\text { diri siswa dalam pembelajaran tematik melalui Strategi Think, Talk, } \\
\text { Write (TTW). Penelitian yang digunakan adalah Penelitian Tindakan } \\
\text { Kelas (PTK) terdiri dari empat tahapan yaitu perencanaan, pelaksanaan, } \\
\text { observasi, dan refleksi. Subjek penelitian yaitu kelas V SD Negeri } 1 \\
\text { Sokaraja Wetan berjumlah } 27 \text { siswa terdiri dari } 14 \text { siswa laki-laki dan } 13 \\
\text { siswa perempuan. Penelitian ini menggunakan teknik non tes. Data sikap } \\
\text { percaya diri siswa diperoleh pada observasi sikap percaya diri yang } \\
\text { diamati setiap pertemuan dan skala sikap percaya diri yang diberikan } \\
\text { kepada siswa pada setiap akhir pertemuan setiap siklusnya. Berdasarkan } \\
\text { penelitian tersebut hasil skala sikap percaya diri siklus I yaitu } \\
\text { memperoleh rata-rata } 79,02 \% \text { dengan kriteria baik dan siklus II } \\
\text { memperoleh rata-rata } 86,92 \% \text { dengan kriteria sangat baik. Hal tersebut } \\
\text { dapat disimpulkan bahwa dengan menggunakan Strategi Think, Talk, } \\
\text { Write (TTW) dapat meningkatkan sikap percaya diri siswa dalam } \\
\text { pembelajaran tematik di kelas V SD Negeri } 1 \text { Sokaraja Wetan. }\end{array}$} \\
\hline Submitted: Ju & \\
\hline Accepted & \\
\hline Published : Feb 2 & \\
\hline Kata Kunci & \\
\hline & \\
\hline
\end{tabular}

\section{PENDAHULUAN}

Pendidikan memiliki peran yang sangat penting untuk menjamin kelangsungan hidup suatu bangsa dan negara, karena pendidikan dapat meningkatkan potensi sumber daya manusia. Undang-undang Sistem Pendidikan Nasional nomor 20 tahun 2003 pasal 1 ayat 1 menyatakan bahwa pendidikan adalah usaha sadar dan terencana untuk mewujudkan suasana belajar dan proses pembelajaran agar siswa secara aktif mengembangkan potensi dirinya untuk memiliki kekuatan spiritual keagamaan, pengendalian diri, kepribadian, kecerdasan, akhlak mulia, serta, keterampilan yang diperlukan dirinya, masyarakat, bangsa, dan negara. Sikap percaya diri merupakan salah satu aspek kepribadian yang sangat penting dalam kehidupan manusia. Seseorang yang percaya diri akan yakin atas kemampuan mereka sendiri serta memiliki harapan yang realistis bahkan ketika harapan mereka tidak terwujud, mereka akan tetap berpikiran positif dan dapat menerimanya.

Pendidikan Sekolah Dasar merupakan jenjang yang paling dasar pada pendidikan formal yang memegang peranan penting untuk mengarahkan berkembangnya potensi yang dimiliki siswa dengan mencerdaskan dan mencetak generasi bangsa sehingga memiliki akhlak yang mulia, ketaqwaan, ilmu, keterampilan, kreatif, sikap percaya diri, berbudi pekerti yang santun. Sesuai dengan kurikulum 2013 kompetensi sikap ada dua yaitu KI-1 sikap spiritual dan KI-2 sikap sosial. Kemdikbud menjelaskan bahwa pada KI-2 sikap sosial aspek penilaian terdiri dari jujur, disiplin, tanggung jawab, santun, peduli, dan percaya diri (Kemdikbud, 2013, p. 8). Mustari

Tyas, D. A., Eka, K. I., \& Wiarsih, C. (2020). Penggunaan Strategi Think, Talk, Write (TTW) terhadap Sikap Percaya Diri Siswa Sekolah 8 Dasar. MUKADIMAH, 4(1), 8-15. 
menyatakan bahwa percaya diri merupakan keyakinan bahwa orang mempunyai kemampuan untuk melakukan sesuatu untuk mencapai tujuan tertentu (Mustari, 2014, p. 51). Berdasarkan definisi tersebut bahwa catatan perilaku siswa dapat dilakukan sesuai indikator pada aspek sikap percaya diri dalam proses pembelajaran sesuai dengan KI.

Proses pembelajaran di kelas diharapkan dapat memunculkan sikap percaya diri dalam diri siswa yang dibantu oleh guru dalam mengelola kelas melalui penerapan strategi pembelajaran. Sikap percaya diri dapat dimunculkan oleh guru dengan memberikan bantuan kepada siswa untuk menemukan kelebihan atau potensi yang dimiliki siswa.

Berdasarkan hasil observasi proses pembelajaran di kelas dan wawancara dengan guru kelas V SD Negeri 1 Sokaraja Wetan bahwa guru masih kesulitan dalam menciptakan suasana belajar yang menyenangkan dan melibatkan siswa secara langsung. Kondisi ini menjadikan siswa tidak mau bertanya dan mengalami kesulitan ketika diberikan soal. Keseriusan siswa dalam belajar masih menjadi masalah yang dihadapi guru, ditunjukan dengan kondisi siswa masih egois, mengandalkan teman, siswa tidak mau menerima pendapat teman yang lain, siswa masih malu-malu dalam menyampaikan pendapat, selain itu saat presentasi siswa tidak mau bergiliran. Permasalahan yang dapat diidentifikasi bahwa siswa kurang memiliki sikap percaya diri untuk tampil di depan kelas, menyampaikan pendapat, tidak berani bertanya, dan mencoba hal baru pada saat proses pembelajaran berlangsung. Permasalahan tersebut dapat dicari solusi yang tepat agar pembelajaran lebih aktif dan menyenangkan, salah satunya dengan menerapkan strategi pembelajaran Think, Talk, Write (TTW).

Secara umum strategi Think, Talk, Write dapat ditempuh melalui 3 tahap yaitu: Think (berpikir) Talk (berbicara) Write (menulis). Penerapan strategi TTW memungkinkan seluruh siswa mengeluarkan ide-ide, membangun secara tepat untuk berpikir dan refleksi, serta mengetes ide tersebut sebelum siswa diminta untuk menulis. Strategi TTW dilakukan dengan siswa memikirkan sendiri untuk menyelesaikan tugas atau masalah dalam lembar kerja siswa, kemudian mengkomunikasikan hasil pemikirannya dalam diskusi yang terdiri atas 3-5 siswa, dalam kelompok ini siswa diminta membaca, membuat catatan kecil, menjelaskan, mendengar, dan membagikan ide bersama teman kemudian mengungkapkan melalui tulisan. Pembelajaran dalam bentuk kelompok kecil, dengan berpikir, membaca, berdiskusi dan menulis, siswa tidak tertekan melakukan diskusi dengan temannya sendiri tanpa ada rasa takut, malu, maupun rendah diri. Pembelajaran menggunakan strategi TTW dapat berjalan dengan baik dan siswa akan lebih aktif dan fokus dalam mengikuti proses pembelajaran sehingga sikap percaya diri siswa akan meningkat.

\section{METODE DAN FOKUS PENELITIAN}

Penelitian ini merupakan Penelitian Tindakan Kelas yang dilaksanakan di SD Negeri 1 Sokaraja Wetan pada semester II Tahun Ajaran 2018/2019. Subjek penelitian adalah siswa kelas V berjumlah 27 siswa yang terdiri dari 14 siswa laki-laki dan 13 siswa perempuan. 
Penelitian ini menggunakan model Penelitian Tindakan Kelas (Classroom Action Research) Kemmis dan McTaggart (Kemmis \& McTaggart, 1982). Arikunto menjelaskan bahwa penelitian tindakan kelas merupakan penelitian yang dilakukan oleh guru, bekerja sama dengan peneliti (atau dilakukan oleh guru sendiri yang juga bertindak sebagai peneliti) di kelas atau di sekolah tempat ia mengajar dengan penekanan pada penyempurnaan atau peningkatan proses dan praktis pembelajaran (Arikunto, 2012, p. 57). Alasan peneliti memilih metode ini karena dilihat dari tujuan PTK sendiri adalah untuk meningkatkan mutu atau kualitas proses dan hasil pembelajaran. Penelitian tindakan kelas ini dilaksanakan dalam empat langkah yaitu perencanaan, pelaksanaan tindakan, observasi, dan refleksi.

Teknik pengumpulan data dalam penelitian ini dengan menggunakan teknik non tes. Teknik non tes terdiri dari observasi sikap, angket sikap dan dokumentasi. Alat pengumpulan data menggunakan lembar angket sikap percaya diri, lembar observasi (lembar observasi guru, lembar observasi siswa dan lembar observasi sikap percaya diri siswa) dan dokumentasi.

\section{HASIL DAN PEMBAHASAN}

\section{Hasil}

Hasil penelitian ini menemukan bahwa terdapat peningkatan sikap percaya diri siswa melalui strategi Think, Talk, Write. Hal tersebut dibuktikan dengan hasil angket/skala sikap percaya diri siswa diperoleh dari pengamatan hasil observasi sikap percaya diri siswa, aktivitas siswa saat proses pembelajaran di dalam kelas dan hasil angket/skala sikap percaya diri siswa. Angket sikap percaya diri siswa diberikan kepada siswa pada pertemuan kedua atau diakhir siklus. Sikap percaya diri siswa mengalami peningkatan setelah menggunakan strategi Think, Talk, Write dari siklus I ke siklus II. Hasil persentase nilai rata-rata hasil sikap percaya diri siswa berkaitan dengan tema 9 benda-benda di Sekitar Kita Kelas V B SD Negeri 1 Sokaraja Wetan dapat dilihat pada tabel 1 berikut:

Tabel 1. Skala Sikap Percaya Diri siswa

\begin{tabular}{|c|l|c|c|}
\hline No & \multicolumn{1}{|c|}{ Indikator } & Siklus I & Siklus II \\
\hline 1 & Pantang menyerah & 150 & 190 \\
\hline 2 & Berani menyatakan pendapat & 145 & 188 \\
\hline 3 & Berani bertanya & 144 & 187 \\
\hline 4 & $\begin{array}{l}\text { Mengutamakan usaha sendiri dari } \\
\text { pada bantuan }\end{array}$ & 143 & 185 \\
\hline 5 & Berpenampilan tenang & 145 & 189 \\
\hline Jumlah & 727 & 939 \\
\hline Rata-rata Skor & 31,60 & 34,77 \\
\hline \multicolumn{2}{|l|}{ Rata-rata Persentase } & $79,02 \%$ & $86,92 \%$ \\
\hline \multicolumn{2}{|l|}{ Kriteria } & Baik & Sangat Baik \\
\hline
\end{tabular}


Hasil sikap percaya diri siswa berdasarkan tabel 1 menunjukkan bahwa adanya peningkatan nilai rata-rata dari siklus I ke siklus II melalui strategi Think, Talk, Write pada siklus I dapat dikategorikan ke dalam kriteria baik dan pada siklus II terjadi peningkatan dengan kriteria sikap percaya diri siswa sangat baik. Hal tersebut diperkuat dengan hasil observasi sikap percaya diri siswa kelas V B SD Negeri 1 Sokaraja Wetan dapat dilihat pada tabel 2 berikut:

Tabel 2. Observasi Sikap Percaya Diri siswa

\begin{tabular}{|c|c|c|c|c|}
\hline No & Siklus & Jumlah & Rata-rata & Kriteria \\
\hline 1 & I & 466 & $61,31 \%$ & Tidak Baik \\
\hline 2 & II & 759 & $80,50 \%$ & Baik \\
\hline
\end{tabular}

Hasil observasi sikap percaya diri siswa berdasarkan tabel 2 menunjukkan bahwa adanya peningkatan rata-rata dari siklus I ke siklus II melalui strategi Think, Talk, Write. Rata-rata hasil observasi sikap percaya diri siswa diperoleh setelah melaksanakan pembelajaran menggunakan strategi Think, Talk, Write, pada siklus I jumlah rata-rata yang diperoleh adalah $61,31 \%$ dengan kriteria tidak baik, sedangkan pada siklus II mengalami peningkatan jumlah rata-rata yaitu 80,50\% dengan kriteria baik. Hal tersebut dikarenakan siswa memiliki rasa ingin tahu yang besar terhadap proses pembelajaran. Sehingga proses pembelajaran yang dilakukan lebih bermakna dan memberikan pengaruh terhadap sikap percaya diri siswa.

\section{Pembahasan}

Pembahasan dalam penelitian tindakan kelas ini didasarkan dari hasil dan catatan selama melaksanakan penelitian. Peningkatan sikap percaya diri siswa dengan penerapan strategi Think, Talk, Write mampu meningkatkan sikap percaya diri siswa kelas V SD Negeri 1 Sokaraja Wetan. Majid menjelaskan bahwa strategi adalah suatu pola yang direncanakan dan ditetapkan secara sengaja untuk melakukan kegiatan atau tindakan (Majid, 2013, p. 3). Pendapat tersebut dapat dijelaskan bahwa stretegi adalah suatu rencana yang akan ditetapkan sebelum melakukan proses kegiatan. Salah satu strategi inovatif yang dapat digunakan dengan penerapan strategi Think, Talk, Write sehingga dapat meningkatkan sikap percaya diri siswa pada siklus I ke siklus II.

Strategi Think, Talk, Write dapat melatih siswa untuk mengungkapkan alasan dari jawaban yang mereka temukan dan melakukan diskusi kelompok untuk pemecahan masalah yang timbul. Huda menjelaskan bahwa Think, Talk, Write (TTW) adalah strategi yang memfasilitasi latihan berbahasa secara lisan dan menulis bahasa tersebut dengan lancar (Huda, 2013, p. 218). Strategi yang diperkenalkan pertama kali oleh Huinker dan Laughlin didasarkan pada pemahaman bahwa belajar adalah sebuah perilaku sosial (Huda, 2013, p. 218). Strategi TTW mendorong siswa untuk berpikir, berbicara, dan menuliskan suatu topik tertentu. Strategi TTW terdapat tiga aktivitas yang dapat membuat siswa aktif dan terlibat langsung dalam proses pembelajaran yaitu berpikir, berbicara, dan menulis. Strategi ini megutamakan adanya kerjasama antar siswa dalam kelompok untuk menyelesaikan masalah yang timbul. 
Sikap percaya diri siswa diukur dengan menggunakan lembar observasi sikap percaya diri dan angket skala sikap percaya diri siswa. Selama proses pembelajaran guru memberikan kesempatan kepada siswa untuk bertanya dan menyatakan pendapat tentang materi yang belum dipahaminya. Percaya Diri merupakan sikap yang penting dimiliki oleh siswa sebagai modal dasar mengembangkan potensi yang ada dalam dirinya. Mustari menjelaskan percaya diri adalah keyakinan bahwa orang mempunyai kemampuan untuk melakukan sesuatu untuk mencapai tujuan tertentu (Mustari, 2014, p. 51). Hasil penjelasan tersebut dapat dikatakan bahwa seseorang yang mempunyai sikap percaya diri yang sangat tinggi tidak bagus dan juga terlalu tidak percaya diri pun tidak bagus. Seseorang memang dididik untuk mempunyai sikap percaya diri, namun sikap percaya diri yang dimaksud adalah percaya diri yang sewajarnya dengan kemampuan dirinya sendiri.

Sikap percaya diri peserta didik yang meningkat tidak lepas dari peran guru yang selalu memberikan motivasi, memberi semangat dan memberikan pujian agar lebih percaya diri pada kemampuan sendiri. Sikap percaya diri dalam pembelajaran memiliki beberapa indikator. Mulyasa menjelaskan bahwa pantang menyerah berati sikap yang tidak mudah patah semangat, berani menyatakan pendapat, berani bertanya, mengutamakan usaha sendiri dari pada bantuan, dan berpenampilan tenang. Hal tersebut sudah dimiliki oleh peserta didik sehingga dalam kegiatan pembelajaran peserta didik lebih percaya diri di kelas dan dengan semangat, bekerja keras dalam mengerjakan tugas kelompok, mengutamakan usaha sendiri tanpa bantuan teman, berani menyatakan pendapat kepada teman yang lain dan kepada guru, berani bertanya tentang materi yang belum dipahaminya pada saat proses pembelajaran, dan berpenampilan tenang saat presentasi maupun menjawab pertanyaan guru, dan temantemannya (Mulyasa, 2013, p. 147).

Peningkatan observasi sikap percaya diri peserta didik dibuktikan ketika proses pembelajaran peserta didik menjadi semakin percaya diri terhadap kemampuan yang dimilikinya. Pendapat tersebut sesuai dengan yang dikemukakan Dariyo menyatakan bahwa percaya diri (self-confidence) ialah kemampuan individu untuk mendapatkan dan meyakini seluruh potensinya agar dapat dipergunakan dalam menghadapi penyesuaian diri dengan lingkungan hidupnya (Dariyo, 2007, p. 206). Berdasarkan pendapat tersebut dapat disimpulkan bahwa sikap percaya diri seseorang dapat dimiliki sesuai dengan potensi yang dimiliki masing-masing.

Observasi sikap percaya diri siswa dilakukan pada setiap pertemuan di setiap siklus. Terjadi peningkatan sikap percaya diri siswa kelas V SD Negeri 1 Sokaraja Wetan menggunakan strategi Think, Talk, Write. Hasil sikap percaya diri siswa pada siklus I memperoleh jumlah keseluruhan 466 dengan nilai rata-rata 61,31\% dengan kriteria tidak baik. Pada siklus II memperoleh jumlah keseluruhan 759 dengan nilai rata-rata $80,50 \%$ dengan kriteria baik. Terjadi peningkatan dari siklus I dan siklus II dari nilai $61,31 \%$ menjadi 80,50\% yaitu sebesar 19,19\%. Hasil observasi sikap percaya diri siswa dapat dilihat sebagai berikut: 


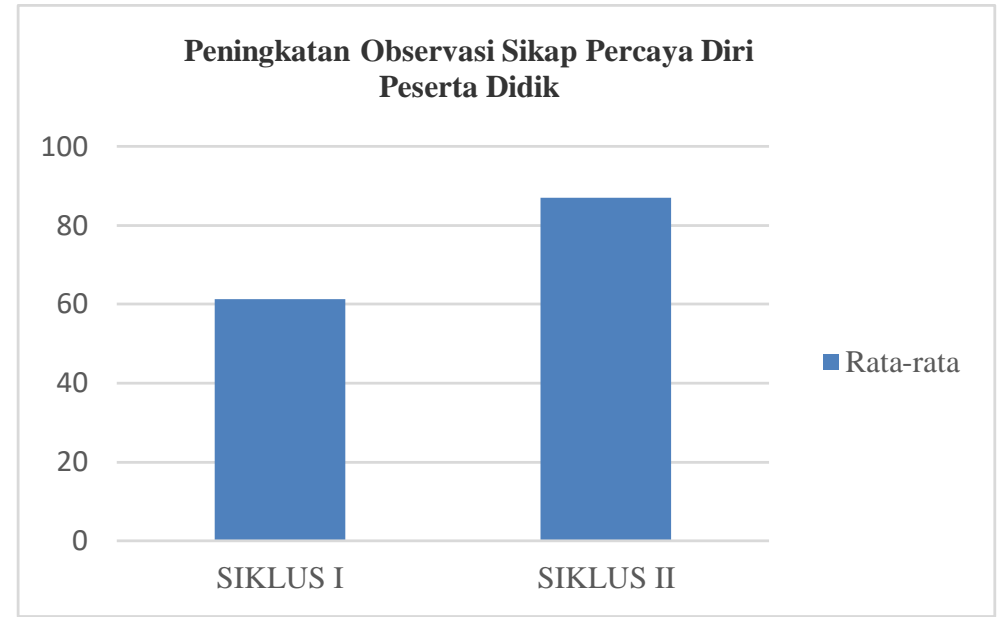

Gambar 1 Diagram Peningkatan Observasi Sikap Percaya Diri siswa Kelas V SD Negeri 1 Sokaraja Wetan

Sikap percaya diri siswa tidak hanya diukur menggunakan observasi namun diperkuat menggunakan angket sikap percaya diri yang diberikan pada siklus I pertemuan 2 dan siklus II pertemuan 2 yang diisi oleh siswa. Hasil angket sikap percaya diri siswa dapat dilihat sebagai berikut:

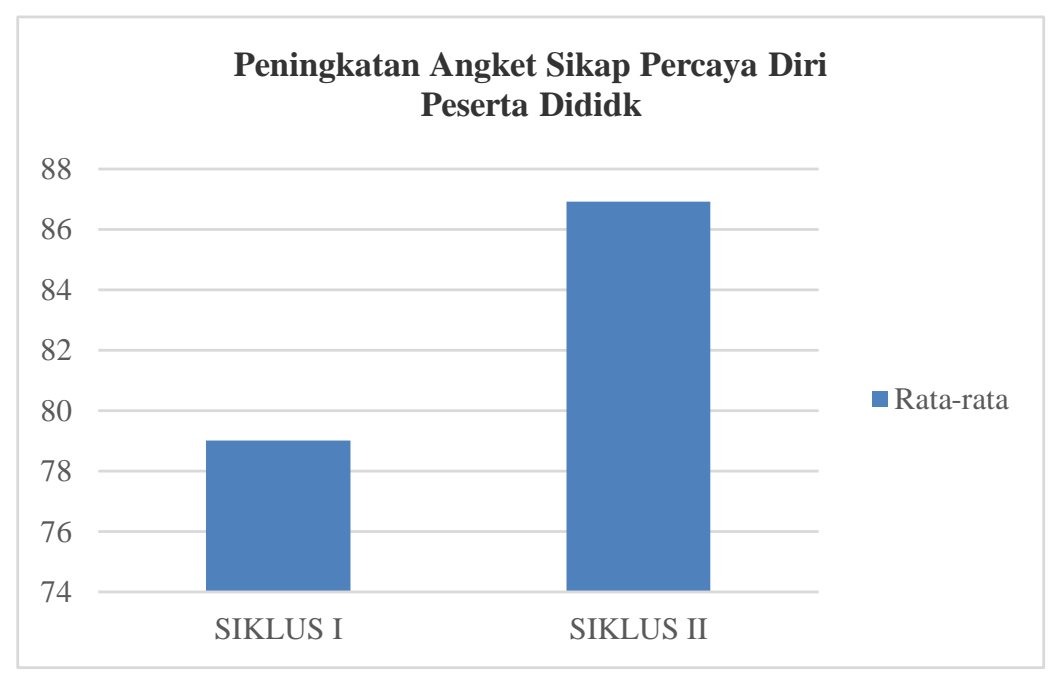

Gambar 2 Diagram Peningkatan Angket Sikap Percaya Diri siswa Kelas V SD Negeri 1 Sokaraja Wetan

Gambar 2 menunjukkan adanya peningkatan rata-rata angket sikap percaya diri siswa pada siklus I yang memperoleh jumlah keseluruhan 727 dengan rata-rata 79,02\% dengan kriteria baik. Siklus II memperoleh jumlah keseluruhan 939 dengan rata-rata angket sikap percaya diri yaitu $86,92 \%$ dengan kriteria sangat baik. Peningkatan dari siklus I dan siklus II sebesar 7,9\%.

Hal ini tidak terlepas dari peranan guru selama proses pembelajaran. Guru memiliki peran penting untuk membimbing siswa dalam meningkatkan sikap percaya diri siswa selama proses pembelajaran dengan menggunakan langkah-langka strategi 
Think, Talk, Write. Huda menjelaskan bahwa langkah-langkah dalam menggunakan strategi Think Talk Write (TTW) yaitu:

1) Siswa membaca teks dan membuat catatan dari hasil bacaan secara individual (Think) untuk dibawa ke forum diskusi.

2) Siswa berinteraksi dan berkolaborasi dengan teman satu grup untuk membahas isi catatan (Talk). Kegiatan ini siswa menggunakan bahasa dan kata-kata mereka sendiri untuk menyampaikan ide-ide saat berdiskusi. Pemahaman dibangun melalui interaksi dalam diskusi, karena itu diskusi diharapkan dapat menghasilkan solusi atas soal yang diberikan.

3) Siswa mengkontruksi sendiri pengetahuan yang memuat pemahaman dan komunikasi dalam bentuk tulisan (Write).

4) Kegiatan akhir pembelajaran adalah membuat refleksi dan kesimpulan atas materi yang dipelajari. Sebelum itu, dipilih satu untuk beberapa siswa sebagai perwakilan kelompok untuk menyajikan jawaban sedangkan kelompok lain diminta memberikan tanggapan (Huda, 2013, p. 220).

Strategi Think, Talk, Write ini membuat siswa menjadi lebih aktif, mandiri dan memiliki sikap percaya diri. Hal tersebut dapat dibuktikan pada langkah-langkah guru menyajikan materi sebagaimana biasanya.

\section{PENUTUP}

Berdasarkan hasil Penelitian Tindakan Kelas yang telah dilakukan selama 2 siklus dalam meningkatan sikap percaya diri siswa melalui strategi Think, Talk, Write pada tema 9 benda-benda di sekitarnya di Kelas V B SD Negeri 1 Sokaraja Wetan telah menunjukkan hasil sesuai dengan yang diharapkan. Hasil penelitian yang diperoleh sebagai berikut:

Penerapan strategi Think, Talk, Write dalam pembelajaran tematik tema 9 benda-benda di sekitarnya dapat meningkatkan sikap percaya diri siswa. Peningkatan ini terlihat tidak hanya dari angket sikap percaya diri yang diisi oleh setiap siswa, tetapi juga dari sikap siswa dalam pembelajaran. Observasi sikap percaya diri siswa siklus I memperoleh rata-rata $61,31 \%$ dengan kriteria tidak baik, mengalami peningkatan pada siklus II dengan memperoleh rata-rata 80,50\% dengan kriteria sangat baik. Skala sikap percaya diri siswa yang diisi oleh siswa pada siklus I memperoleh rata-rata $79,02 \%$ dengan kriteria baik, sedangkan pada siklus II mengalami peningkatan menjadi 86,92\% dengan kriteria sangat baik.

Berdasarkan pada kesimpulan hasil perbaikan pembelajaran dalam Penelitian Tindakan Kelas (PTK) di atas, peneliti menyadari sepenuhnya adanya keterbatasan baik waktu dan tenaga serta kemampuan yang dimiliki oleh peneliti sendiri. Ada beberapa hal yang harus diperhatikan dalam melakukan suatu penelitian pembelajaran di kelas, antara lain:

1) Saat proses pembelajaran, sebaiknya konsisten dalam mengaitkan materi pembelajaran dengan kehidupan sehari-hari, dan juga memberikan umpan balik kepada siswa agar lebih termotivasi untuk menyimpulkan pendapat yang dimiliki dan mengajukan pertanyaan mengenai materi yang belum diajarkan. 
2) Saat proses pembelajaran guru perlu membuat siswa lebih aktif di kelas dan sebaiknya juga menggunakan media pembelajaran agar siswa tidak mudah bosan.

3) Guru hendaknya selalu memberikan pesan moral di setiap akhir pembelajaran agar siswa dapat mencontoh perilaku sikap yang positif dalam kegiatan apapun.

\section{REFERENSI}

Arikunto, S. (2012). Dasar-dasar Evaluasi Pendidikan. Jakarta: PT Bumi Aksara.

Dariyo, A. (2007). Psikologi Perkembangan Anak Tiga Tahun Pertama. Bandung: PT Refika Aditama.

Huda, M. (2013). Model-model Pengajaran dan Pembelajaran. Yogyakarta: Pustaka Pelajar.

Kemdikbud. (2013). Panduan Teknis Penilaian di Sekolah Dasar. Jakarta: Dirjen Pendidikan Dasar.

Kemmis, S. \& McTaggart, R. (1982). The Action Research Planner. Geelong Australia: Daekin University Press.

Majid, A. (2013). Strategi Pembelajaran. Bandung: PT Remaja Rosdakarya.

Mulyasa. (2013). Pengembangan Implementasi Kurikulum 2013. Bandung: PT Remaja Rosdakarya Offset.

Mustari, M. (2014). Nilai Karakter Refleksi untuk Pendidikan. Jakarta: PT RajaGrafindo Persada.

Undang-Undang Republik Indonesia No. 20 tentang Sistem Pendidikan Nasional.

Widoyoko, E. P. (2018). Teknik Penyusunan Instrumen Penelitian. Yogyakarta: Pustaka Pelajar. 